\title{
Effect of milk thistle (Sylibum marianum L.) endosperm in the diet for cows on milk yield and fatty acid profiles
}

\author{
A. Potkański ${ }^{1}$, J. Kowalczyk ${ }^{2}$, W. Nowak ${ }^{1}$, M. Czauderna ${ }^{2}$ \\ and S. Michalak ${ }^{1}$
}

\author{
'Institute of Animal Nutrition and Feed Management, \\ August Cieszkowski Agricultural University \\ Wotyńska 33, 60-637 Poznań, Poland \\ ${ }^{2}$ The Kielanowski Institute of Animal Physiology and Nutrition, \\ Polish Academy of Sciences \\ 05-110 Jablonna, Poland
}

ABSTRACT

The experiment was carried out on 30 multiparous Black-and-White Lowland cows from 45 to 70 days of lactation, divided into three groups according to calving date and milk yield, and fed a basic ration consisting of maize, grass and sugar beet pulp silages with concentrate for the control group. In both of experimental groups, $20 \%$ of concentrate was substituted with endosperm from milk thistle (Sylibum marianum L.) and 3\% of calcium carbonate, but in one of the experimental groups, $1.5 \%$ of buffering sodium carbonate was additionally added to the concentrate mixture. Endosperm of milk thistle contained $23 \%$ fat with a high proportion of unsaturated fatty acids.

The mean fat content in the milk of the experimental groups was similar $(4.83$ and $4.61 \%$, respectively) but significantly higher $(\mathrm{P}<0.05)$ compared with the control group $(4.27 \%)$. A decline in the percentage of short-chain $\left(\mathrm{C}_{8: 0}, \mathrm{C}_{10: 0}, \mathrm{C}_{12: 0}\right)$ and medium-chain $\left(\mathrm{C}_{14: 0,0} \mathrm{C}_{16: 0}\right)$ fatty acids was observed along with a simultancous advantageous, from the dietary point of view, increase in the percentage of unsaturated fatty acids $\left(\mathrm{C}_{18: 0,} \Delta-6-\right.$ cis- $\mathrm{C}_{18: 1,} \Delta-9-12-$ cis- $\left.\mathrm{C}_{18: 2}\right)$ in the milk of cows of the experimental groups.

KEY WORDS: dairy cows, endosperm from milk thistle, milk composition, fatty acids 


\section{INTRODUCTION}

Endosperm from milk thistle (Sylibum marianum L.) (EMT) contains a high level of unsaturated fatty acids, particularly $\Delta-9,12-c i s-C_{18: 2}$, which are essential for animals. Increasing the content of unsaturated fatty acids from the n-3 and n-6 groups in milk is of great importance from the consumer's point of view. One of the methods facilitating modification of milk fat composition is to use feeds containing a high concentration of unsaturated fatty acids (Schingoethe et al., 1996). Unfortunately, the introduction of unprotected fat with a predominance of unsaturated fatty acids has an adverse effect on ruminal metabolism, primarily the utilization of structural carbohydrates (Michalak and Nowak, 2000). Moreover, a significant amount of these acids undergoes hydrogenation and, in this way, reduces the amount of unsaturated fatty acids in milk (Jenkins, 2000). These processes might be restricted by adding calcium compounds (Drackley et al., 1994) or buffers (Solorzano et al., 1989) to the diet.

The study was aimed at determining the effect of milk thistle (Sylibum marianum L.) endosperm and buffering substances on milk yield and its chemical composition.

\section{MATERIAL AND METHODS}

In an experiment lasting 8 weeks, 30 multiparous Black-and-White Lowland cows with an average $72 \% \mathrm{HF}$ blood share, between 45 to 70 days after calving, were divided into three groups according to calving date and milk yield. The cows were fed a daily basic ration that consisted of maize silage, $8.8 \mathrm{~kg}$; grass silage, $5.5 \mathrm{~kg}$, and sugar beet pulp silage, $2.2 \mathrm{~kg}$, with $7.5 \mathrm{~kg}$ (DM basis) concentrate for the control group (C); in the experimental groups $20 \%$ of the concentrate was substituted with endosperm $(1.5 \mathrm{~kg}$ ) from milk thistle (Silibum marianum L.) and $3 \%$ calcium carbonate (group MT) or $20 \%$ endosperm, $3 \%$ calcium carbonate, and $1.5 \%$ of buffering sodium carbonate (group MTB).

The nutritive value of feeds was calculated according to the IZ-INRA (1997) method. Daily intake of protein truly digestible in the small intestine dependent on the amount of $\mathrm{NH}_{3}-\mathrm{N}$ (PDIN) was 2002, 2018, and 2017 g; protein truly digestible in the small intestine dependent on the amount of energy (PDIE) was 2008,2012 and $2010 \mathrm{~g}$; units for milk production (UFL), 19.8, 20.5 and 20.5 for groups C, MT and MTB, respectively. The cows were milked twice daily and once a week milk daily samples were analyzed for protein content using Foss Milco-Scan equipment. On days 21 and 56 of the experimental period, milk samples were analyzed for fatty acid composition according to the Heining et al. (1998) HPLC method. 
The data were subjected to the statistical analysis of variance using SAS software $(1996)$. Duncan's multiple range test $(\mathrm{P}<0.05)$ was used to test the significance of the difference between means.

\section{RESULTS}

In $1 \mathrm{~kg}$ of dry matter, milk thistle endosperm (Sylibum marianum L.) (EMT) contained $230 \mathrm{~g}$ of crude protein and $398 \mathrm{~g}$ crude fat with a predominance of unsaturated fatty acids: $\Delta-9,12-c i s-C_{18: 2}\left(70.8 \mathrm{~g} 100 \mathrm{~g}^{-1}\right.$ of total FA), $\Delta-9-c i s-\mathrm{C}_{18: 1}$

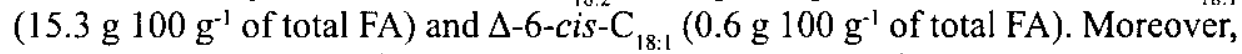

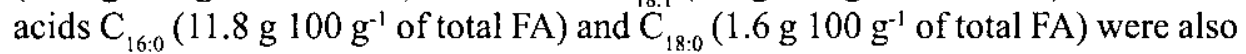
found.

The average daily milk yield did not differ significantly $(\mathrm{P}<0.05)$ between groups (Table 1) and ranged from $33.1 \mathrm{~kg}$ in group $\mathrm{C}$ to $34.7 \mathrm{~kg}$ in group MT. In comparison with the control group $(\mathrm{C}, 4.3 \%)$ a statistically significant increase $(\mathrm{P}<0.05)$ was observed for fat content in milk from cows fed milk thistle endosperm with added $\mathrm{Ca}$ (MT, 4.83\%) as well as the addition of calcium carbonate and sodium carbonate as buffering substances (MTB, 4.61\%) but differences between experimental groups were not significant $(\mathrm{P}>0.05)$. Milk thistle endosperm did not have a significant effect $(\mathrm{P}>0.05)$ on the milk yield and protein content.

TABLE 1

Mean daily milk yield, fat and protein content in milk

\begin{tabular}{lccc}
\hline & \multicolumn{3}{c}{ Groups } \\
\cline { 2 - 4 } Item & $\mathrm{C}$ & $\mathrm{MT}$ & MTB \\
\hline Daily milk yield, kg & 33.1 & 34.7 & 33.2 \\
Fat, \% & $4.27^{\mathrm{a}}$ & $4.83^{\mathrm{b}}$ & $4.61^{\mathrm{b}}$ \\
Fat, g/day & $1413^{\mathrm{n}}$ & $1676^{\mathrm{b}}$ & $1530^{\mathrm{b}}$ \\
Protein, \% & 3.12 & 3.14 & 3.19 \\
Protein, g/day & 1032 & 1089 & 1059 \\
\hline
\end{tabular}

a.b means with different superscripts within rows differ $(\mathrm{P}<0.05)$

The addition of $20 \%$ EMT had a significant effect $(\mathrm{P}<0.05)$ on the change in the fatty acid profile (Table 2). Increased percentages of fatty acids $C_{18: 1}, \Delta-6$-cis$\mathrm{C}_{18: 1}$ and $\Delta-9,12-$ cis- $\mathrm{C}_{18: 2}$ were observed in the groups fed concentrate with added milk thistle. However, only the content of $\Delta-6-c i s-\mathrm{C}_{18: 1}$ acid was higher in a signifi-

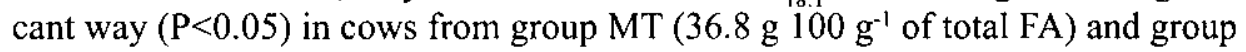

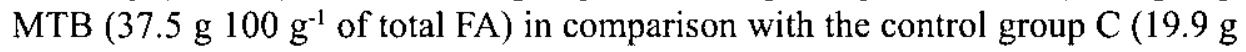
$100 \mathrm{~g}^{-1}$ of total FA). At the same time, an advantageous decrease, from the dietary 
TABLE 2

Fatty acid composition of milk fat, g per $100 \mathrm{~g}$ of total fatty acids

\begin{tabular}{lcccc}
\hline \multirow{2}{*}{ Fatty acids } & \multicolumn{3}{c}{ Groups } & SEM \\
\cline { 2 - 4 } & $2.22^{\mathrm{a}}$ & $1.67^{\mathrm{b}}$ & $1.94^{\mathrm{ab}}$ & 0.08 \\
\hline $\mathrm{C}_{8: 0}$ & $4.45^{\mathrm{a}}$ & $3.47^{\mathrm{b}}$ & $3.28^{\mathrm{b}}$ & 0.15 \\
$\mathrm{C}_{10: 0}$ & $4.66^{\mathrm{a}}$ & $3.44^{\mathrm{b}}$ & $2.90^{\mathrm{b}}$ & 0.23 \\
$\mathrm{C}_{12: 0}$ & $10.96^{\mathrm{a}}$ & $8.50^{\mathrm{b}}$ & $7.57^{\mathrm{b}}$ & 0.41 \\
$\mathrm{C}_{14: 0}$ & $28.39^{\mathrm{a}}$ & $17.90^{\mathrm{b}}$ & $18.87^{\mathrm{b}}$ & 1.47 \\
$\mathrm{C}_{16: 0}$ & 6.34 & 7.38 & 8.36 & 0.43 \\
$\mathrm{C}_{18: 0}$ & & & & \\
$\Delta-6-$ trans $-\mathrm{C}_{18: 1}$ & 0.56 & 0.51 & 0.57 & 0.04 \\
$\Delta-7-$ trans-C & $0.18: 1$ & 0.09 & 0.09 & 0.02 \\
$\Delta-9-$ trans $-\mathrm{C}_{18: 1}$ & 0.37 & 0.29 & 0.47 & 0.05 \\
$\Delta-6-$ cis $-\mathrm{C}_{18: 1}$ & $19.9^{\mathrm{a}}$ & $36.78^{\mathrm{b}}$ & $37.51^{\mathrm{b}}$ & 0.12 \\
$\Delta-9-$ cis $-\mathrm{C}_{18: 1}$ & 16.66 & 13.54 & 12.81 & \\
& & & & 0.32 \\
$\Delta-9,12-$ cis $-\mathrm{C}_{18: 2}$ & 4.24 & 5.59 & 4.95 & 0.02 \\
$\Delta-9,12,15-$ trans-C & 0.04 & 0.04 & 0.08 & 0.02 \\
$\Delta-6,9,12-$ cis $-\mathrm{C}_{18: 3}$ & $0.27^{\mathrm{a}}$ & $0.16^{\mathrm{b}}$ & 0.16 & 0.03 \\
$\Delta-9,12,15-$ cis- & $0.75_{18: 3}^{\mathrm{a}}$ & $0.62^{\mathrm{ab}}$ & $0.58^{\mathrm{b}}$ & \\
\hline
\end{tabular}

a,b means with different superscripts within rows differ $(\mathrm{P}<0.05)$

SEM - standard error of mean

point of view, was observed in the percentage of short-chain $\left(\mathrm{C}_{8: 0}, \mathrm{C}_{10: 0}\right.$ and $\left.\mathrm{C}_{12: 0}\right)$ and medium-chain $\left(\mathrm{C}_{14: 0}\right.$ and $\left.\mathrm{C}_{16: 0}\right)$ acids in both experimental groups. The contents of $\Delta-6,9,12-c i s-\mathrm{C}_{18: 3}$ and $\Delta-9,12,15-c i s-\mathrm{C}_{18: 3}$ acids in the groups fed milk thisthe endosperm with the addition of $\mathrm{Ca}(\mathrm{MT})$ and $\mathrm{Ca}$ together with $\mathrm{NaHCO}_{3}(\mathrm{MTB})$ were significantly lower $(\mathrm{P}<0.05)$. The concentration of $\Delta-9-$ cis $-\mathrm{C}_{18: 1}$ was lower for groups MT and MTB in comparison with that in the control group (C); however, the differences between groups were not significant $(\mathrm{P}>0.05)$.

\section{DISCUSSION}

The administration of $1.5 \mathrm{~kg}$ endosperm of milk thistle (Sylibum marianum L.) ( $20 \%$ concentrate, approx. $600 \mathrm{~g}$ of oil/d) had no significant effect on milk yield or milk protein content. Slightly higher milk yield was observed in cows fed the MT diet (EMT with calcium carbonate). Murphy et al. (1990) reported a significant increase in cow performance as a result of including $15 \%$ ground rape seeds into the concentrate and no significant effect of whole rape seeds. Strzetelski et al. (1999) reported a tendency to supplement cows' diets with evening primrose seeds 
(Oenothera paradoxa) to increase milk production and fat content. Also Nowak and Potkański (2000) recorded a non-significant increase in the yield of milk after the addition of 1.4 rolled rape seed. In the present study on dairy cows receiving supplemental fat from EMT, a significant increase in milk fat content and daily milk fat production was found, suggesting that calcium and sodium bicarbonate reduced the negative effects of unsaturated and unprotected fatty acids on fibre digestion in the rumen and rumen fermentation. Chouinard et al. (1995) suggested that an increased concentration of trans $\mathrm{C}_{18: 1}$ in milk is always observed during milk fat depression. In the present study there was no significant effect of EMT on the concentration of trans $\mathrm{C}_{18: 1}$ fatty acids in milk, while the fat content in milk increased. The vegetable fat from EMT consisted of unsaturated fatty acids in the cis form. Garnsworthy (1997) pointed out that fatty acids in the trans form have a much greater inhibitory effect on milk fat concentration than those in the cis form. Palmquist et al. (1990) speculated that a higher fat content could have been the result of long-chain fatty acids passing from the feed to milk directly in the mammary gland, thus saving energy on their synthesis. Palmquist and Jenkins (1980) suggested that polyunsaturated fatty acids inhibit the growth of ruminal microbes, which may reduce microbial digestion of fibre, acetate production or protein synthesis as the fatty acid contents increase in the ration, unless these fatty acids were made insoluble by transformation into Ca salts. In the present study, milk protein content was not affected by the addition of EMT, thus confirming that fat from milk thistle endosperm supplemented with calcium carbonate inhibited microbial protein synthesis in the rumen. Khorasani et al. (1991) suggested that lower milk protein production might be related to lower acetate production in the rumen, which could increase the utilization of amino acids as an energy substrate. On the other hand, Casper and Shingoethe (1989) suggested that a higher level of fat in the diet of ruminants reduces mammary uptake of amino acids by inhibiting the release of somatotropin.

The fatty acid composition of milk fat may be altered by dietary manipulation. Milk products containing less saturated fatty acids and more saturated $\mathrm{C}_{: 18}$ may be desirable as they lower the risk of coronary heart disease (Noakes et al., 1996). Fat from the endosperm of milk thistle (Sylibum marianum L.) consists of unsaturated fatty acids, mainly $\Delta-9,12-c i s-C_{18: 2}(70 \%)$. Including EMT into the diet significantly increased the content of $\Delta-6$-cis- $\mathrm{C}_{18: 1}$ and reduced the concentrations of shortand medium-chain fatty acids. Garnsworthy (1997) concluded that increasing the intake of fat may increase the proportion of unsaturated fatty acids in milk fat, since the de novo synthesis of short-chain fatty acids is reduced and these are all saturated. Similar results, using other types of vegetable fat, were obtained by Shingoethe et al. (1996) and Nowak and Potkański (2000). Banks (1987) pointed out that higher levels of oleic acid in milk fat are due either to increased dietary $\mathrm{C}_{18: 1}$ as a result of partial hydrogenation in the rumen, or increased desaturation of 
$\mathrm{C}_{18: 0}$ in the gut wall and mammary glands. Long-chain fatty acids are generated from the mobilization of body reserves or from dietary sources, while short chain fatty acids are synthesized in the mammary gland. The changes in milk fat composition in this study were probably influenced by partial rumen biohydrogenation of fatty acids from EMT and passing them directly to the milk fat.

\section{CONCLUSIONS}

In the conclusion of this study it should be stated that endosperm of milk thistle (Sylibum marianum L.) may be fed with calcium carbonate as a component of concentrates for high yielding cows. Endosperm from the milk thistle supplement considerably increased the concentration of monounsaturated fatty acids $(\Delta-6$-cis$\mathrm{C}_{18: \mathrm{l}}$ ) in milk fat, which has been promoted as a change favourable for human health in respect to hypercholesterolemia.

\section{REFERENCES}

Banks W., 1987. Opportunities for varying the composition of cow's milk. J. Soc. Dairy Tech. 40, 96-99

Casper D.P., Shingoethe D.J., 1989. Model to describe and alleviate milk protein depression in early lactation dairy cows fed high fat diet. J. Dairy Sci.72, 3327-3335

Chouinard P.Y., Girard V., Brisson G.J., 1995. Influence of calcium salts of fatty acids (CSFA) with varying unsaturation on yield, composition, and fatty acid profile in Holstein milk. Can. J. Anim. Sci. 75, 656 (Abstr.)

Drackley J.K., Grum D.E., McCoy G.C., Klusmeyer T.H., 1994. Comparison of three methods for incorporation of liquid fat into diets for lactating dairy cows. J. Dairy Sci. 77, 1386-1398

Garnsworthy P.C., 1997. Fat in dairy cow fats. In: P.C. Garnsworthy, J. Wiseman (Editors). Recent Advances in Animal Nutrition. Nottingham University Press, pp. 87-104

Heinig K., Hissner F., Martin., Vogt C., 1998. Separation of saturated fatty acids by capillary electrophoresis and HPLC. Amer. Lab., May, 24-29

IZ-INRA, 1997. Standards for Cattle, Sheep and Goat Nutrition (in Polish). Research Institute of Animal Production, Kraków. Omnitech Press, Warszawa (Poland)

Jenkins T.C., 2000. Feeding oleamide to lactating Jersey cows 1. Effects on lactation performance and milk fatty acid composition. J. Dairy Sci. 83, 332-337

Khorasani G.R., Robinson P.H., De Bocr G., Kennelly J.J., 1991. Influence of canola fat on yield, fat percentage fatty acid profile, and nitrogen fractions in Holstein milk. J. Dairy Sci.74, 1904-1911

Michalak S., Nowak W., 2000. Effect of supplemental rapeseed oil in wheat bran and in dried sugar beet pulp on the rate of ruminal degradation of structural carbohydrates. Ann. Anim. Sci. 27, $149-160$

Murphy J.J., McNeill G.P., Connoly J.F., Gleeson P.A., 1990. Effect of cow performance and milk fat composition of including full fat soybeans and rapeseeds in the concentrate for lactating cows. J. Dairy Res. 57, 295-306 
Nowak W., Potkański A., 2000. The effect of rolled rape seeds on milk composition and lactational responses. J. Anim. Feed Sci. 9, 425-434

Noakes M., Nestel P.J., Clifton P.M., 1996. Modifying the fatty acids profile of dairy products through feedlot technology lowers plasma cholesterol of humans consuming the products. Amer. J. Clin. Nutr. 63, 42-46

Palmquist D.L, Jenkins T.C., 1980. Fat in lactation rations: review. J. Dairy Sci. 63, 1-14

Palmquist D.L., 1990. The strategic use of fat in dairy ration. Bull. Nat. Rend. Assoc. 784, 8-9

SAS $^{\mathfrak{Q}}$ User's Guide: Statistics, Version 6.12. 1996. SAS Inst., Inc., Cary, NC

Schingoethe D.J., Brouk M.J., Lightfield K.D., Baer R.J., 1996. Lactational responses of dairy cows fed unsaturated fat from extruded soybeans or sunflower seeds. J. Dairy Sci. 79, 1244-1249

Solorzano L.C., Armentano L.E., Grummer R.R., Dentine W.R., 1989. Effects of sodium bicarbonate or sodium sesquicarbonate on lactating Holsteins fed a high grain diet. J. Dairy Sci. 72, 453-461

Strzetelski J.A., Kowalczyk J., Stasiniewicz T., Lipiarska E., Osięglowski S., Bilik K., 1999. Milk yield and composition in dairy cows fed a diet with evening primrose (Oenothera paradoxa) full fat or oil cake. J. Anim. Feed Sci. 8, 89-94

\section{STRESZCZENIE}

\section{Wplyw bielma ostropestu plamistego (Silibum marianum L.) w dawkach dla krów na wydaj- ność mleczną i profil kwasów tluszczowych}

Doświadczenie przeprowadzono na 30 krowach ncb, od 45 do 70 dnia laktacji, podzielonych na 3 grupy według daty wycielenia i wydajności mleka. Krowom podawano dawkę podstawową złożoną z kiszonek $z$ kukurydzy, trawy i wysłodków buraczanych, oraz paszy treściwej. $20 \%$ mieszanki treściwej dla obydwóch grup doświadczalnych zastapiono bielmem nasion ostropestu plamistego $\mathrm{z}$ dodatkiem $3 \%$ węglanu wapnia, a w jednej z grup doświadczalnych do mieszanki treściwej dodano $1,5 \%$ weglanu sodowcgo. Bielmo ostropestu plamistego zawierało $23 \%$ tłuszczu o dużej zawartości nienasyconych kwasów tłuszczowych.

Średnia zawartość tluszczu w mleku krów grup doświadczalnych nie różniła się istotnie i wynosiła odpowiednio 4,83 i 4,61\%, ale była istotnie większa $(\mathrm{P}<0,05)$ niż w grupie kontrolnej $(4,27 \%)$. $\mathrm{W}$ tłuszczu mleka krów grup doświadczalnych karmionych dawkami z bielmem ostropestu plamistego stwierdzono mniejszą zawartość kwasów tiuszczowych o krótkim $\left(\mathrm{C}_{8: 0}, \mathrm{C}_{10: 0}, \mathrm{C}_{12: 0}\right)$ i średnim $\left(\mathrm{C}_{14: 0 \text {, }}\right.$ $\mathrm{C}_{16: 0}$ ) łańcuchu węglowym, a większą zawartość, pożądanych z punktu widzenia dietetycznego, kwasów nienasyconych $\left(\mathrm{C}_{18: 0,} \Delta-6-\right.$ cis- $\mathrm{C}_{18: 1,1} \Delta-9-12-$ cis- $\left.\mathrm{C}_{18: 2}\right)$ niż w thuszczu mleka krów grupy kontrolnej. 